\title{
Corporate Social Responsibility, Program Bedah Rumah dan Upaya Pengentasan Kemiskinan di Kabupaten Kulon Progo
}

\author{
S.L. Harjanta \\ Prodi Administrasi Publik Universitas Widya Mataram \\ harjanto@ymail.com
}

\begin{abstract}
Based on the poverty album, the poverty rate in Kulon Progo Regency is still quite high. Data for 2015 states that the poverty rate is above 20 percent or around 50 thousand people. Of the tens of thousands of poor people, many of them live in unfit for habitation. With the issuance of Regional Regulation (Perda) number 22 of 2012 concerning Corporate Social Responsibility, the private sector or entrepreneurs have the responsibility to alleviate poverty in Kulon Progo Regency. For this reason, this study will examine the extent to which the role of CSR or the involvement of entrepreneurs in poverty alleviation efforts, particularly through the house renovation program. The location of this research is in Kulon Progo Regency, Yogyakarta Special Region Province. Meanwhile, the type of research used is descriptive qualitative research.
\end{abstract}

Keywords: Corporate Social Responsibility, Uninhabitable Houses, Poverty Reduction Policies

\section{Pendahuluan}

Kemiskinan adalah masalah sosial terbesar di dunia dan setiap Negara berusaha untuk mengatasinya. Kemiskinan adalah faktor yang sangat menentukan maju tidaknya suatu negara. Kemiskinan tidak hanya sekedar tidak terpenuhinya kebutuhan dasar. Namun juga terkait dengan pendidikan dan kesehatan yang kondisinya tidak baik (Adam Smith:1776).

Kemiskinan membuat seseorang belum bisa melengkapi keperluan dasar dirinya dan keluarganya yang mencangkup kebutuhan fisik, mental dan sosial. Tidak terpenuhinya kebutuhan dasar, akan berdampak pada kesulitan anggota keluarga dan juga sosial. Tempat tinggal merupakan salah satu keperluan dasar manusia yang tidak derajatnya juga sama penting dari sandang dan pangan. Menurut data Bappenas, 2003, dalam konteks kebijakan penyelenggaraan perumahan yang tidak terpusat, saat ini belum tersedia sistem yang ideal.

Angka kemiskinan Kabupaen Kulon Progo cukup tinggi. Ini berdasarkan data tahun 2015, dimana dalam album kemiskinan disebutkan warga miskin mencapai lebih dari 20 persen atau sekitar 50 ribu penduduk. Dari puluhan ribu warga miskin tersebut, sebagian besar tinggal di rumah tidak layak huni. Menurut Budihardjo (2009), permasalahan dalam bidang perumahan di Indonesia adalah sedikitnya pemenuhan perumahan yang layak huni dan dengan harga terjangkau. Khususnya bagi warga miskin. Kondisi ini dikarenakan, warga miskin tidak mampu untuk mendapatkan atau membeli rumah dalam kondisi layak. Kondisi 
itu diperparah dengan system subsidi perumahan yang buruk.

Menurut Santoso (2002), berdasarkan permasalahan tersebut, maka dibutuhkan intervensi dari pemerintah. Intervensi ini dalam bentuk pemerintah menyediakan infrastruktur dan kebijakan yang tepat. Bagi kalangan yang tidak mampu, maka pemerintah harus memberikan subsudi. Hal ini merupakan konsekuensi jika negara mengakui bahwa perumahan merupakan kebutuhan dasar.

Selain pemerintah, pihak swasta juga memiliki tanggung jawab dalam penanggulangan kemiskinan. Keterlibatan serta tanggung jawab kalangan swasta di Kulon Progo dalam penanggulangan kemiskinan juga diatur dalam Perda khusus. Yakni Perda Nomer 22 Tahun 2012 Tentang Tanggung Jawab Sosial Perusahaan (TSP). TSP merupakan istilah lain dari Corporate Social Responsibility atau CSR.

A. Rumusan Masalah

Berdasar latar belakang tersebut, maka dalam penelitian ini ada dua rumusan masalah.

1. Bagaimana peran kalangan swasta melalui program CSR dalam upaya pengentasan kemiskinan melalui program bedah rumah di Kabupaten Kulon Progo?

2. Seberapa besar dampak peran swasta melalui program CSR dalam program bedah rumah?

B. Tujuan dan Manfaat Penelitian

Tujuan penelitian ini adalah, pertama untuk mengetahui seberapa jauh peran kalangan swasta melalui program Corporate Social Responsibility (CSR) dalam upaya mengurangi kemiskinan, melalui program bedah rumah. Yang kedua, penelitian ini bertujuan untuk mengetahui seberapa besar dampak CSR terhadap program bedah rumah di Kabupaten Kulon Progo.

Sementara itu, manfaat dari penelitian ini adalah :

1. Secara teoritis, penelitian ini diharapkan dapat memberikan kontribusi dalam kajian CSR atau keterlibatan swasta dalam upaya pengentasan kemiskinan, khususnya melalui program bedah rumah.

2. Secara praktis, penelitian ini diharapkan dapat menjadi pertimbangan pemerintah dalam kebijakan penanggulangan kemiskinan, baik di tingkat pusat maupun di daerah.

Pendapat Djojohadikusumo (1994) bisa menjadi rujukan alternative untuk melihat bagaimana kemiskinan iu muncul. Menurutnya, kemiskinan hadir sebagai akibat kesenjangan ekonomis sosiologis dan juga ekonomi regional. Dia menambahkan, kemiskinan terjadi sebagai akibat ketidakseimbangan kekuatan yang sangat mencolok diantara golongan-golongan pelaku ekonomi. Dalam kondisi ini, pengusaha kakap cenderung mengandalkan kekuatan sumberdayanya untuk mendapatkan posisi di pasar barang dan jasa. Selain dari dimensi ekonomi dan non ekonomi, kemiskinan juga bisa disebabkan dimensi geografis. Sebuah keluarga yang berasal dari rumah tangga miskin dapat memiliki kesempatan yang lebih besar untuk keluar dari kemiskinan. Sementara itu, keluarga miskin yang berada pada wilayah yang tidak mendukung, cenderung menjadi stagnan dan bahkan menjadi sangat miskin.

Sementara itu, menurut BPS ada beberapa indikator kemiskinan. Yaitu konsumsi beras, tingkat pendapatan, pengeluaran rumah tangga, kebutuhan fisik minimum, kebutuhan dasar.

A. Rumah 
Rumah adalah tempat perlindungan utama bagi manusia dari iklim, kemudian juga dari gangguan fisik lainnya. Rumah merupakan suatu basis pemeliharaan kemampuan produksi, tempat beristirahat, tempat untuk memelihara kesehatan, juga tempat untuk belajar dan mempersiapkan diri (Santoso, 2002:39).

Sedangkan untuk ciri Rumah Tidak Layak Huni (RTLH) sehingga seseorang masuk kategori KK miskin, ada 5 indikator. 5 indikator ini bagian dari 16 ciri/ indikator kategori KK miskin.

Ciri RTLH tersebut meliputi: 1.Luas, 2.Jenis dinding rumah, 3.lantai, 4.MCK, dan 4.Sambungan listrik. 1.Luas rumah, siapa yang menggunakan luas rumah kurang dari 8 m2/ orang maka masuk kategori miskin. Jika 4 jiwa, maka minimal 32 m2. 2.Dinding rumah, jika terbuat dari kayu atau bambu berbahan dasar murah.

3.Dasar Lantai, jika masih dari tanah maka masih kategori KK miskin. 4.MCK, jika masih buang air besar sembarangan, maka masuk kategori KK miskin.

5.Jika rumah tidak ada sambungan listrik, maka masuk kategori KK miskin.

B. Corporate Social Responsibility

$$
\text { Corporate }
$$

Social

Responsibility adalah aktivitas tanggung jawab yang dilakukan perusahaan terhadap dampak negatif yang ditimbulkan dari aktivitas operasional yang meliputi tanggung jawab ekonomi, sosial, dan lingkungan (Marsden, 2001 dalam Dahlsurd, 2008). Nathaniel (2012) mengatakan bahwa saat ini dunia usaha tidak lagi hanya memperhatikan laporan keuangan semata (single bottom line) tetapi juga memperhatikan tiga aspek penting yang meliputi aspek keuangan, lingkungan, dan sosial (triple bottom line).

Sedangkan Bulan dan Astika (2014) berpandangan, sebuah perusahaan yang ingin maju, harus memperhatikan 3P. Yaitu planet, people, dan profit. Seperti konsep triple bottom line dimana selain mendapatkan laba (profit) sebuah perusahaan juga harus memperhatikan kesejahteraan masyarakat (people) serta ikut berperan aktif dalam menjaga keberlangsungan lingkungan (planet).

Sementara itu, berdasar Perda nomer 22 Tahun 2012 Tanggung Jawab Sosial Perusahaan dibagi menjadi tiga. Ini sesuai dengan Pasal 13 Perda TSP. Pada pasal tersebut dijelaskan, program TSP meliputi :

1. Bina lingkungan dan social

2. Kemitraan usaha mikro kecil dan koperasi

3. Program langsung pada masyarakat.

Sementara itu, program bedah rumah Kabupaten Kulon Progo masuk dalam poin ke tiga. Yakni program langsung pada masyarakat.

\section{Metode Penelitian}

A. Jenis Penelitian

Jenis penelitian ini adalah penelitian deskriptif kualitatif, karena penelitian ini berusaha mengungkapkan suatu fakta atau peristiwa sebagaimana adanya dan memberikan gambaran secara obyektif tentang keadaan dan permasalahan. Sebagaimana dijelaskan Moleong (2015 : 11), penelitian deskriptif berisi kutipan data atau memberi gambaran penyajian laporan dan setiap bagian ditelaah satu persatu. Moleong menambahkan, penelitian kualitatif adalah penelitian yang menghasilkan prosedur analisis yang tidak menggunakan prosedur analisis statistik atau cara kuantitatif lainnya.

Konsep lain menjelaskan bahwa penelitian kualitatif adalah penelitian yang bertujuan untuk memahami fenomena tentang apa yang dialami oleh subyek peneliti. Misal perilaku, persepsi, motivasi, tindakan dan lain-lain, secara holistik dan dengan cara deskriptif dalam bentuk kata dan bahasa, pada 
suatu konteks khusus yang alamiah dengan memanfaatkan berbagai metode ilmiah.

B. Lokasi Penelitian

Penelitian ini mengambil lokasi di wilayah Kabupaten Kulon Progo, Provinsi Daerah Istimewa Yogyakarta. Di mana di mana, di kabupaten tersebut terdapat 12 kecamatan.

C. Sumber Data

1. Data Primer

Data yang didapat dengan datang langsung ke tempat penelitian yang akan dilakukan, yaitu hasil dari observasi, wawancara dan angket.

2. Data Sekunder

Data yang diperoleh dari penelitian bahan pustaka dengan cara mengumpulkan data yang terdapat dalam peraturan perundangundangan, buku dan juga artike.

D. Teknik Pengumpulan Data

Teknik pengumpulan data menggunakan sumber primer dan sumber sekunder. Sumber primer adalah sumber data yang langsung memberikan data pada pengumpul data. Sedangkan data sekunder adalah sumber data yang tidak langsung memberikan data pada pengumpul data (Sugiyono, 2010 : 156).

Sementara itu, teknik pengumpulan data dalam penelitian ini dilakukan dengan cara sebagai berikut :

1. Wawancara

Wawancara digunakan sebagai teknik pengumpulan data apabila peneliti ingin melakukan studi pendahuluan untuk menemukan permasalahan yang harus diteliti dan apabila peneliti ingin mengetahui hal-hal dari responden yang lebih mendalam dan jumlah respondennya sedikit.

2. Observasi

Teknik pengumpulan data dengan observasi digunakan bila peneliti berkenaan dengan perilaku manusia, proses kerja, gejalagejala alam dan bila responden yang diamati tidak terlalu besar (Sugiyono, 2010 : 166). Penggunaan metode ini bertujuan untuk melihat kenyataan di lapangan secara langsung. Sehingga, dapat diketahui proses pelayanan dan fenomena yang terjadi diamati dari dekat.

3. Dokumentasi

Ini merupakan suatu metode pengumpulan data yang digunakan dalam metodelogi social. Pada intinya, metode documenter adalah metode yang digunakan untuk menelusuri data historis (Bungin, 2013 : 153-154). Dalam penelitian ini juga menggunakan teknik dokumentasi dalam pengumpulan data berdasar dokumen-dokumen yang ada. Baik berupa laporan, catatan, berkas dan bahan tertulis lainnya.

E. Informan Kunci

Dalam penelitian ini, ada beberapa pihak yang akan menjadi informan kunci. Antara lain :

1. Kepala Daerah atau Bupati Kulon Progo (1 orang)

2. Ketua Forum CSR Kabupaten Kulon Progo (1 orang)

3. Kalangan swasta atau pengusaha (4 orang)

4. Penerima program bedah rumah (6 orang)

Dengan demikian total informan kunci dalam riset ini sebanyak 12 orang atau narasumber.

F. Teknik Analisis Data

Dalam penelitian ini, data yang berhasil dihimpun baik data yang bersifat numerik atau kuantitatif maupun kualitatif dianalisis dengan menggunakan metode analisa kualitatif. Data akan diolah dengan 
analisa yang bersifat induktif dengan pendeskripsian. Hal tersebut cocok dengan apa yang dikatakan Sugiyono, 2011 : 13. Menurutnya, metode penelitian kualitatif digunakan untuk mendapatkan data yang mendalam, suatu data yang mengandung makna. Makna adalah data yang sebenarnya, data yang pasti merupakan suatu nilai di balik data yang tampak. Oleh karena itu dalam penelitian kualitatif tidak menekankan pada generalisasi, tetapi lebih menekankan pada makna.

Dalam penelitian ini analisis daya yang digunakan adalah teknik analisis interaktif (Mills dan Huberman, 1992 : 20). Analisi interaktif dilakukan dalam empat alur kegiatan yang terjadi secara bersamaan. Yaitu

\section{Pengumpulan Data}

Pengumpulan data merupakan upaya untuk mengumpulkan datadata yang diperlukan dalam penelitian. Adapun metode pengumpulan data yang dilakukan adalah dengan berbagai macam cara. Antara lain, wawancara, angket, obeservasi dan dokumentasi.

2. Reduksi Data

Reduksi data adalah proses memilih, memfokuskan, menyederhanakan dan membuat abstraksi, mengubah data mentah yang dikumpulkan dari penelitian ke dalam catatan yang telah disortir atau diperiksa. Tahap ini merupakan tahapan analisis data yang mempertajam atau memusatkan, membuat dan sekaligus dapat dibuktikan.

3. Penyajian Data
Penyajian data yaitu sebagai kumpulan informasi tersusun yang memberikan kemungkinan adanya penarikan kesimpulan atau pengambilan tindakan. Pengambilan data ini membantu penulis memahami peristiwa yang terjadi dan mengarah pada analisis atau tindakan lebih lanjut berdasarkan pemahaman.

4. Penarikan Kesmimpulan

Penarikan kesimpulan adalah merupakan langkah terakhir meliputi makna yang telah disederhanakan. Disajikan dalam pengajuan data dengan cara keteraturan, pola-pola penjelasan secara logis dan metodologis, konfigurasi yang memungkinkan diprediksikan.

\section{Hasil dan Pembahasan}

Sementara itu, berdasar album kemiskinan Kabupaten Kulon Progo, jumlah warga miskin tahun 2015 mencapai lebih dari 20 persen atau sekitar 50 ribu penduduk. Dari puluhan ribu warga miskin tersebut, sebagian besar tinggal di rumah tidak layak huni. Program bedah rumah memang lazim dilakukan banyak kepala daerah di Indonesia. Yang membuat beda, program di Kulon Progo tak sepenuhnya dibiayai oleh APBN/ APBD maupun APBDes namun juga pihak di luar pemerintah. Berpatokan pada Laporan Keterangan Pertanggungjawaban (LKPJ) tahun 2015 dan Laporan Keterangan Pertanggungjawaban Akhir Masa Jabatan (LKP-AMJ) 2011-2016, Pemerintah Kabupaten Kulon Progo mendata telah melakukan bedah rumah sebanyak 696 buah. Yang menarik, dalam memperbaiki 696 rumah itu, berhasil menyerap dana swadaya masyarakat sebanyak Rp13,96 miliar. Sementara itu bantuan stimulan (APBD) yang dikeluarkan sebanyak Rp6,96 miliar. 
Namun berdasarkan keterangan Bupati terpilih Hasto Wardoyo, jumlah rumah tidak layak huni yang diperbaiki melalui program bedah rumah hingga awal 2017 telah mencapai lebih dari 1. 300 rumah. Dari angka itu, dia menyebut mayoritas anggaran berasal dari kalangan swasta dan juga zakat dari PNS di lingkungan Pemkab Kulon Progo.

"Bedah rumah dengan cara
gotong royong ini mencapai
sekitar $1.300 \quad$ rumah.
Anggarannya banyak berasal
dari bantuan swasta dan zakat
PNS. Jumlah (bedah rumah) ini
di luar yang dilakukan
pemerintah pusat" (Wawancara
12/3/2017)

Seperti diketahui, pemerintah pusat melalui kementrian Pekerjaan Umum (PU) juga menggulirkan program bedah rumah. Dalam program ini, anggaran bedah rumah sepenuhnya ditanggung oleh anggaran yang bersumber dari APBN.

Hasto memiliki istilah lain dalam menyebut dana swadaya masyarakat ini dengan menyebut sebagai dana 'gotongroyong'. Dana 'gotong-royong' berasal dari beberapa sumber. Diantaranya, keutungan dari rekanan (kontraktor) dan sumbangan 2,5 persen dari gaji PNS di lingkungan Pemkab Kulon Progo. Selain dua sumber itu, dana program bedah rumah juga berasal dari pihakpihak lain (kompas.com 16/12/2015).

Berdasar data di lapangan, ada tiga skema dalam pelaksanaan program bedah rumah 'gotong-royong' ini. Pertama bedah rumah yang dilakukan oleh Forum Corporate Social Responsibility (CSR). Kedua melalui Bazas Kulon Progo dan ketiga langsung melalui Hasto Wardoyo.
Bagan. 1

Skema Pengelolaan Program Bedah Rumah “Gotong royong”

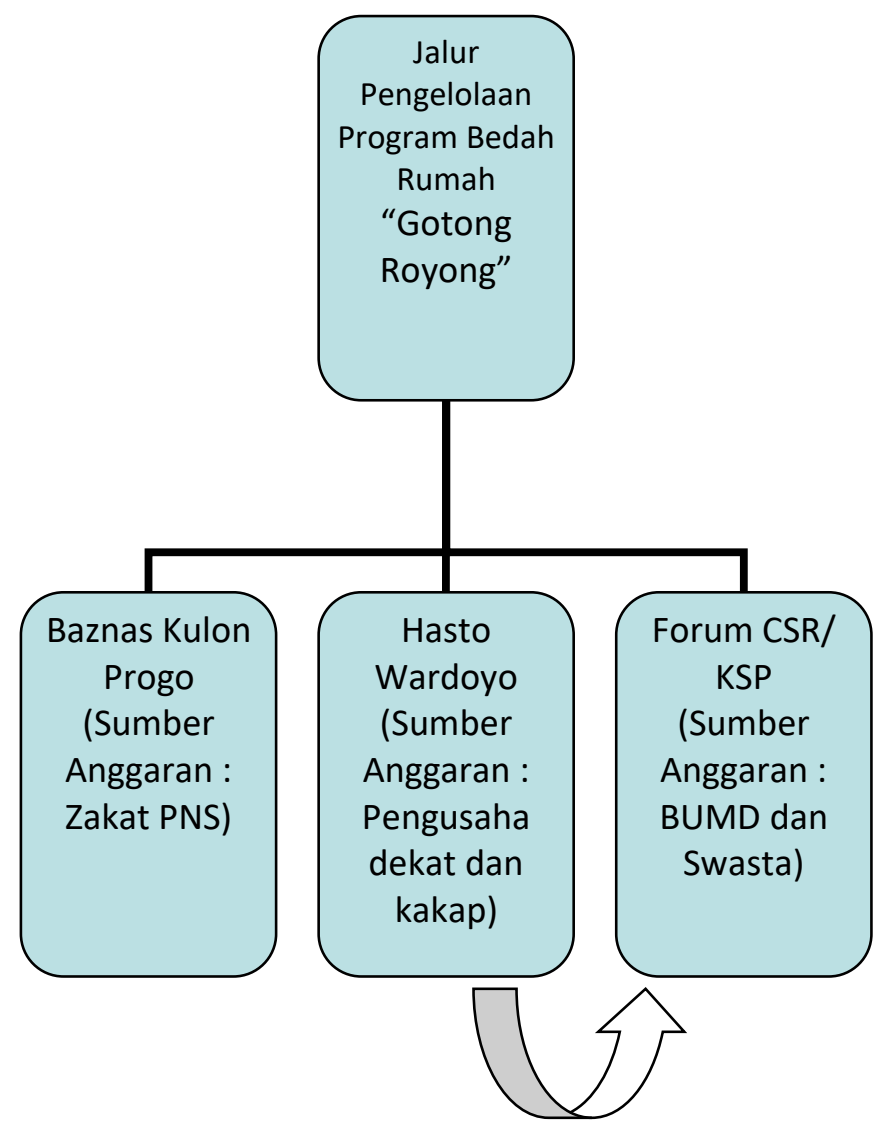

Program housing upgrading subsidy ini pembiyaannya bersumber dari kalangan swasta dan juga BUMD. Dalam program ini, berhasil menggalang dana swasta sebesar Rp13,96 miliar (LKP-AMJ 20112016). Beberapa pihak yang jadi penyokong program populis tersebut antara lain Gapensi/Gapeksindo, Gapeknas, PT. Jaya Makmur Prayoga Sentosa, PT. Jogja Magasa Iron (JMI), PD. BPR. Bank Pasar KP, PT. Selo Adikarto, PDAM Tirta Binangun, Perum Aneka Usaha Kulon Progo dan PT. Bank BNI 46. 
Sebagai dasar hukum dalam penggalangan dana dari pengusaha, Pemda Kulon Progo membuat Perda no 22 Tahun 2012 tentang Tanggung Jawab Sosial Perusahaan (TSP). Perda ini lahir tak lama setelah Hasto menjabat sebagai bupati periode pertama, yakni pada 2011 lalu. Dalam Perda itu antara lain soal kewajiban pengusaha untuk menyisisihkan sebagian keuntungannya untuk membantu masyarakat tidak mampu dan pembentukan Forum Pelaksana Tanggung Jawab Sosial Perusahaan (TSP). Nah, forum TSP ini lah yang kemudian banyak melakukan aktivitas program bedah rumah. Berdasar dokumen yang ada, Forum TSP saat ini dijabat Jumantoro. Jumantoro juga diketahui sebagai orang dekat Hasto yang saat ini menjabat sebagai Direktur PDAM Tirta Binangun. Sementara itu bertindak sebagai Kepala Sekretariat TSP adalah Rita Purwanti Erni Widiyati yang saat ini juga menjabat Direktur PD BPR Bank Pasar Kulon Progo. Keduanya, sebagai pengurus Forum Pelaksana TPS masa bakti 2013-2016.

Keberadaan Forum CSR/ TPS ini cukup berhasil dalam menggalang dana dari kalangan BUMD maupun pihak swasta. Pada tahun 2015, Forum CSR berhasil menghimpun dana hingga Rp706.431.420. Sementara itu pada 2016 meningkat menjadi Rp859.407.719. (Data lengkap dalam tabel.

Tabel.2

Penyumbang Dana TSP Tahun 2015

\begin{tabular}{|l|l|l|}
\hline No & Nama Perusahaan & $\begin{array}{l}\text { Jumlah Dana TSP } \\
\text { (RP) }\end{array}$ \\
\hline 1 & $\begin{array}{l}\text { Gapensi/Gapeksindo, } \\
\text { Gapeknas }\end{array}$ & 233.250 .000 \\
\hline 2. & PD. BPR. Bank Pasar KP & 223.938 .450 \\
\hline 3. & PT. Selo Adikarto & 115.743 .000 \\
\hline 4. & PDAM Tirta Binangun & 58.500 .000 \\
\hline 5. & PT. Bank BNI 46 & 50.000 .000 \\
\hline 6. & PT. Jaya Makmur Prayoga & 5.000 .000 \\
\hline
\end{tabular}

\begin{tabular}{|l|l|l|}
\hline & Sentosa & \\
\hline 7. & PT. Jogja Magasa Iron (JMI) & 20.000 .000 \\
\hline & Jumlah & $\mathbf{7 0 6 . 4 3 1 . 4 2 0}$ \\
\hline
\end{tabular}

Pada tahun 2016 lalu, jumlah hasil penggalangan dana yang dikelola Forum CSR lebih besar. Data lengkap ada di tabel di bawah ini.

Tabel.3

Penyumbang Dana TSP Tahun 2016

\begin{tabular}{|l|l|l|}
\hline No & Nama Perusahaan & $\begin{array}{l}\text { Jumlah Dana TSP } \\
(\mathrm{RP})\end{array}$ \\
\hline 1 & $\begin{array}{l}\text { Gapensi/Gapeksindo, } \\
\text { Gapeknas }\end{array}$ & 207.700 .000 \\
\hline 2. & PD. BPR. Bank Pasar KP & 292.352 .475 \\
\hline 3. & PT. Selo Adikarto & 163.452 .704 \\
\hline 4. & PDAM Tirta Binangun & 78.000 .000 \\
\hline 5. & $\begin{array}{l}\text { Perum Aneka Usaha } \\
\text { Kulon Progo }\end{array}$ & 17.902 .540 \\
\hline & Jumlah & $\mathbf{8 5 9 . 4 0 7 . 7 1 9}$ \\
\hline
\end{tabular}

Kulon Progo

Sumber : Forum CSR/ KSP

Anggaran yang berasal penggalangan dana swasta maupun BUMD tersebut kemudian digunakan untuk membiayai sejumlah kegiatan social. Antar lain bedah rumah, paket sembako, keagamaan hingga jambanisasi. Berdasarkan data Forum KSP, sebagian besar dana yang terkumpul digunakan untuk pembiayaan program bedah rumah. Pada tahun 2015 lalu, program bedah rumah ini menyedot anggaran hingga Rp246.675.000 atau 36 persen dari total anggaran yang dikelola oleh Forum KSP. 
Tabel.4

Penyaluran Dana TSP Tahun 2015

\begin{tabular}{|l|l|l|}
\hline No & Program & Dana (Rp) \\
\hline 1. & Bedah Rumah & 246.675 .000 \\
\hline 2. & Penataan Kota Wates & 143.500 .000 \\
\hline 3. & Sponsorship & 74.000 .000 \\
\hline 4 & Keagamaan & 72.625 .000 \\
\hline
\end{tabular}

Sumber : Data Forum KSP

"Memang kebanyakan dana CSR atau KSP banyak digunakan untuk pembiayaan bedah rumah. Meski menyedot dana besar, kita masih kewalahan untuk memenuhi permintaan perbaikan bedah rumah. Sebab proposal yang masuk ke kita sangat banyak dan tidak sebanding dengan anggaran yang ada." (Wawancara, Ketua KSP, Jumantoro, 24/3/2017)

Terkait dengan penggalian dana dari pihak swasta, Hasto mengaku memiliki alasan tersendiri. Dia menyebut sebelumnya ada budaya suap di kalangan pengusaha untuk mempermudah mendapat izin. Untuk menghapus budaya tersebut, kemudian dia mendorong agar para pengusaha menyalurkan dananya untuk program bedah rumah. Lantas apa kompensasi yang diberikan pada pengusaha yang ikut menyumbang program bedah rumah? Baik Hasto maupun Ketua Forum CSR, Jumantoro secara halus menyebut tidak ada kompensasi atau kemudahan apapun pada pengusaha yang telah menyumbang. Kendati begitu, salah satu PNS di Dinas yang memiliki proyek cukup besar menyebut, pengusaha yang telah menyumbang melalui CSR maupun langsung akan mendapatkan perhatian khusus dalam proses tender ataupun lelang.

\section{Kesimpulan}

Dalam program bedah rumah di Kabupaten Kulon Progo, DIY, pemerintah daerah melibatkan pihak lain untuk melaksanakan program tersebut. Pihak lain tersebut antara lain adalah kalangan swasta termasuk di dalamnya para kontraktor. Sebagai payung hukum, Pemda Kulon Progo telah menyiapakan Perda no 22 Tahun 2012 tentang Tanggung Jawab Sosial Perusahaan (TSP). Dalam Perda ini diatur soal kewajiban pihak swasta menyisisihkan keuntungan untuk membantuk masyarakat kurang mampu di sekitar perusahaan. Selain itu, Perda TSP juga mengatur tentang berdirinya Forum CSR yang memiliki fungsi menghimpun dana dari pihak swasta maupun BUMD. Dana yang dikelola Forum CSR itu lah yang kemudian digunakan untuk kegiatan sosial, antara lain untuk pendanaan proyek bedah rumah.

Pada tahun ke tahun, jumlah dana yang dihimpun oleh Forum CSR terus meningkat. Pada tahun 2015, dana yang terhimpun mencapai angka Rp 700 Juta lebih. Pada tahun 2016, jumlahnya naik menjadi Rp 800 Juta lebih. Dana ratusan juta itu lah yang kemudian digunakan untuk mendanai program sosial, salah satunya program bedah rumah.

Kendati bantuan pihak swasta mengucur melalui Forum CSR, namun uluran tangan pihak swasta tersebut tak bisa secara tuntas menyelesaikan persoalan rumah tidak layak di Kabupaten Kulon Progo. Seperti diketahui, berdasar album kemiskinan tahun 2015, ada sekitar 50 ribu warga miskin di Kabupaten Kulon Progo. Sebagaian besar 
warga miskin tersebut hidup di rumah yang tidak layak.

\section{Daftar Pustaka}

Bakhit, Izzedin (ed), 2001, Menggempur Akaakar Kemiskinan. Jakarta, YakomaPGI.

Chambers, Robert, 1983, Pembangunan Desa Mulai dari Belakang, Jakarta, LP3ES.

Effendi, Tadjuddin Noer, 1992, Sumber Daya Manusia, Peluang Kerja dan
Kemiskinan, Yogyakarta, Tiara Wacana.

Gilbert, Alan \& Josef Gugler, 1996, Urbanisasi dan Kemiskinan di Dunia Ketiga, Yogyakarta, Tiara Wacana.

Suyanto, Bagong dan Karnaji, 2005, Kemiskinan dan Kesenjangan : Ketika Pembangunan Tidak Berpihak pada Rakyat, Surabaya, Airlangga University Press.

Suyanto, Bagong, 2013, Anatomi Kemiskinan dan Strategi Penanganannya, Malang, In-Trans Publishing.

Chamsyah, Bachtiar, 2012, Kemiskinan Sebagai Isu Global 